\title{
Cancer Nanotechnology
}

\author{
Mohammed Chyad Al-Noaemi* \\ Department of Emergency Medical Services, Al-Ghad International College for Applied Medical Sciences, KSA
}

Submission: February 05, 2018; Published: February 12, 2018

*Corresponding author: Mohammed Chyad Al-Noaemi, Department of Emergency Medical Services, Al-Ghad International College for Applied Medical Sciences, Najran, KSA, Tel: 00966538385057; Email: mohammedalnoaemi@gmail.com

\section{Opinion}

Nanotechnology is the study of extremely small structures, having size of 0.1 to $100 \mathrm{~nm}$. In 1959, the lecture of the American physicist Richard Feynman, "There's Plenty of Room at the Bottom", inspired the conceptual foundations of nanotechnology many years later.

The Japanese scientist called Norio Taniguchi of Tokyo University of Science was first to use the term "nano-technology" in a 1974 conference. However, the term was not used again until 1981 when the American scientist "Eric Drexler", who was unaware of Taniguchi's prior use of the term, published his first paper on nanotechnology in 1981. Eric Drexler developed and popularized the concept of nanotechnology and founded the field of molecular nanotechnology.

Nanotechnology has direct beneficial applications for medicine, environment, engineering, biology, chemistry, computing, materials science, and communications. The future of nanotechnology is boundless, according to some speakers. Some of the items that exist today were a topic of science fiction a decade ago and have the potential to transform our society very quickly, as it has been said by Douglas Mulhall.

Advancement in the field of nanotechnology and its applications to the field of medicines and pharmaceuticals has revolutionized the twentieth century. Nano medicine is a relatively new field of science and technology which concern with the medical application of nanotechnology. The approaches to nanomedicine range from the medical use of nanomaterials, to nanoelectronics biosensors, and even possible future applications of molecular nanotechnology.

The main medical applications of nanotechnology are in the fields of; (1) Imaging and diagnostics known as theranostic; (2) Therapeutics which include cancer treatment, bone treatment, and pharmaceutical drug delivery system. The journal Nature Materials estimated that 130 nanotech-based drugs and delivery systems were being developed worldwide.

Nano medicine provides early detection, improved diagnosis, and proper treatment of cancer. Researchers are using antibodies attached to carbon nanotubes in chips to detect cancer cells in the blood stream. They developed a sensor that can detect a very low level of cancer cells, as low as 3 to 5 cancer cells in a one milliliter in a blood sample. Furthermore, Magnetic nanoparticles that attach to cancer cells in the blood stream may allow the cancer cells to be removed before they establish new tumors (preventing metastasis).

\section{Cancer Nano-Therapy}

Nanoparticle can be functionalized with ligands, including small molecules, DNA or RNA strands, peptides, aptamers or antibodies. These ligands can be used for therapeutic effect or to direct nanoparticle fate in vivo.

Nanotechnology in Cancer Treatment includes:

A. Nanotechnology offers the means of drug delivery (chemotherapies) system, which will allow nanoparticles to accumulate directly and selectively to cancerous cells and neoplasms. A method being developed to fight bladder cancer uses nanoparticles called micelles to deliver a chemotherapy drug called paclitaxel to bladder cancer cells. Several members of the Alliance are working towards developing nanomaterialbased delivery platforms that will reduce the toxicity of chemotherapeutics and increase their overall effectiveness

B. Nanoparticles (nanoshells) accumulate at the cancer cells through its targeting molecules and then it concentrates the heat from infrared light, and then by re-radiation it will destroy cancer cells and at the same time it will keep the healthy cells intact. Targeted heat therapy is being developed to destroy breast cancer tumors.

C. Nanoparticles Delivering or Augmenting Radiotherapy. The use of conventional radiotherapy will kill the cancer cells by damaging their DNA inducing cellular apoptosis, but at the same time it is toxic to the healthy surrounding tissue or organs near the tumor mass.

D. Scientists have utilized X-ray triggered drug-releasing nanoparticles that deliver drug locally at tumor site or to 
sensitize the cancer cells to radiotherapy in combination with the drug. Others have used nanomaterials made of a lanthanideor hafnium-doped high-Z core, once injected these can be externally irradiated by X-rays allowing the nanoparticle core to emit the visible light photons locally at the tumor site, destroying the cancer cells but not the healthy cells.

E. Nanoparticles Delivering Immunotherapy. This includes use of nanoparticles for delivery of immunostimulatory or immunomodulatory molecules, a method to increase the number of cancer fighting immune cells in cancer tumors. Nanoparticles containing drug molecules called interleukins are attached to immune cells (T-cells). The idea is that when the T-cells reach a tumor the nanoparticles release the drug molecules, which cause the T-cells to reproduce. If enough T-cells are reproduced in the cancer tumor the cancer can be destroyed. This method has been tested on laboratory mice with very good results.

F. Nanoparticles Delivering Gene Therapy. Delivery of short interfering RNAs (siRNA) is interesting because siRNA simply stops the cancer tumor from growing and there is the potential to tailor synthetic siRNA to the version of cancer in an individual patient. A method being developed to fight skin cancer uses gold nanoparticles to which RNA molecules are attached. The nanoparticles are in an ointment that is applied to the skin. The nanoparticles penetrate the skin and the RNA attaches to a cancer related gene, stopping the gene from generating proteins that are used in the growth of skin cancer tumors.
Your next submission with Juniper Publishers will reach you the below assets

- Quality Editorial service

- Swift Peer Review

- Reprints availability

- E-prints Service

- Manuscript Podcast for convenient understanding

- Global attainment for your research

- Manuscript accessibility in different formats

( Pdf, E-pub, Full Text, Audio)

- Unceasing customer service

Track the below URL for one-step submission https://juniperpublishers.com/online-submission.php 